\title{
A Review on Serenoa serrulata: A Potential Medicinal Plant for Prostatic Diseases
}

\author{
Jacqueline Aber ${ }^{a, b}$, Bruhan Kaggwa ${ }^{a, c}$, Hedmon Okella ${ }^{a}$, Clement Olusoji Ajayia, Patrick Engeu \\ Ogwang \\ PharmBiotechnology and Traditional Medicine Center, Faculty of Medicine, Mbarara University of Science and Technology. P.O Box 1410, Mbarara-Uganda. \\ Department of Pharmacy, Faculty of Medicine, Gulu University. P.O Box 166, Gulu Uganda. \\ cDepartment of Pharmacy, College of Health Sciences, Makerere University. P.O Box 7062, Kampala, Uganda. \\ *Correspondence to Jacqueline Aber (jackieaber2@gmail.com)
}

\begin{abstract}
Background: Prostatic diseases which include prostatitis, benign prostatic hyperplasia (BPH) and prostate cancer are the benign or malignant disorders that affect the prostate. Phytotherapies have been adopted as the alternative treatment/ management option especially for BPH since the current modern methods of treatment presents a lot of adverse effects.

Methodology: The literature was searched using different databases including Medline/PubMed, Cochrane library, Scopus, Proquest library, Embase, EBooks and Google Scholar for relevant records for a period from 1988 to 2021 to identify all the published articles of $S$. serrulata regarding treatment of prostatic diseases. The key search terms were Serenoa serrulata, $\mathrm{S}$. repens, Saw palmetto, Prostate cancer treatment with Serenoa serrulata, treatment of Benign Prostatic Hyperplasia with Serenoa serrulata, phytochemicals of Serenoa serrulata, ethnobotanical uses of Serenoa serrulata, toxicity of Serenoa serrulata, pharmacological activities of Serenoa serrulata and also traditional management and treatment of prostatic diseases using Serenoa serrulata and also clinical trials on treatment of prostatic diseases with Serenoa serrulata. The retrieved articles were reviewed, synthesized and analyzed qualitatively. The reference list of the retrieved articles was also reviewed and synthesized. The original research articles which reported an investigation of $S$. serrulata of any study design, original published research articles, any time of publication and grey literature (conference papers, reported articles, academic thesis) were included. The articles whose full texts were not freely available by the time of search and those without clear information about methodology and study design were excluded.
\end{abstract}

Results: This review reported that Serenoa serrulata belonging to the Arecaceae family commonly known as saw palmetto is used traditionally for treating prostatic disease conditions and other infertility conditions in both men and women. Phytochemical screening of hexanic and ethanolic extracts of $S$. serrulata comprised of free fatty acids and phytosterols which together contribute to their antiprostatic activities. These extracts of $S$. serrulata exhibited antiandrogenic, anti-inflammatory and antiproliferative activities through inhibition of both isoenzymes $5 \alpha$-reductase and inhibition of binding of dihydrotestosterone (DHT) to the cytosolic androgen receptors. This is a similar mechanism exhibited by finasteride and Tamsulosin both antiprostatic conventional drugs though the plant phytochemicals do not interfere with PSA secretion. S. serrulata has also been reported to be non-toxic in both non-clinical and clinical trial studies. The medicinal plants reported by this review to be used in combination include; stinging nettle (Urtica dioca), Zingiber officinalis, Echinacea angustifolia and pumpkin (Cucurbita pepo). The antiprostatic conventional drugs reported include Finasteride and Tamsulosin.

Conclusion and Recommendation: The results showed that $S$. serrulata is effective in treating prostatic diseases. The potency and safety are improved when used in combination with Urtica dioca, Cucurbita pepo, Zingiber officinalis and Echinacea angustifolia as compared with anti-prostatic conventional drugs Finasteride and Tamsulosin alone. The plant combination has also been shown to have improvement in the quality of life and as well enhancing the synergy of Finasteride and Tamsulon and 
their adverse effects. Effective medicinal plant combinations should be formulated into products and integrated into the usual treatment for prostatic diseases.

Key words: Prostatic diseases, Prostate Cancer, Benign Prostatic Hyperplasia, prostate tumors, Phytotherapy, anti-prostatic drugs, Serenoa serrulata, ethnobotanical, phytochemical, toxicity and pharmacological.

\section{INTRODUCTION}

$\operatorname{Pr}^{\mathrm{r}}$ rostatic diseases are the benign or malignant disorders affecting the prostate. Common examples of prostatic diseases include Prostatitis, Benign Prostatic Hyperplasia $(\mathrm{BPH})$ and Prostate cancer. ${ }^{1}$ Prostatitis is an inflammatory disease mainly caused by infections or related health conditions affecting mainly younger and middle aged men characterised by symptoms of pain and discomfort around the anus, scrotum and the area in between. ${ }^{1}$ This mainly occurs in men younger than 35 years. Benign Prostatic Hyperplasia (BPH), a non-cancerous growth of the prostate is so common in older men over the age of 60 years causing an enlargement of the prostate. Statistics show that $92 \%$ of men from the age of 31 to 40 years do not have symptoms of BPH and this increases with age to only $10 \%$ not showing symptoms of $\mathrm{BPH}$ from the age of 60 years and above. ${ }^{2,3}$ This non-cancerous growth is mainly caused by proliferation of the stroma and epithelia cells of the prostate. However, it is a slow progressing and noncancerous condition leading to an impediment of the urethra causing difficulty in urination. The treatment goal of BPH has always been to relieve irritative (urgency, frequency and nocturia) and obstructive (weak stream, hesitancy, intermittency and incomplete emptying) symptoms. ${ }^{4}$ Prostate Cancer (PC), a slow growing cancer that occurs in the prostate is the second most common malignancy in adult male over the age of 65 worldwide. ${ }^{4}$. This slow growing cancer accounts for $7.1 \%$ of all cancers in men with about 1,276,106 new cases annually. 5,6 Though with variations in the statistics among countries and continents. ${ }^{6}$ This is a fatal disease which grows slowly and do not spread beyond the prostate, however some are aggressive and spread quickly to other areas of the body. ${ }^{1}$ Prostate cancer and Benign Prostatic Hyperplasia whose pathogenesis and progression are due to inflammation are chronic prostatic diseases with a long period of development and progression. The factors minimising cell apoptosis and stimulating proliferation create an imbalance existing effects. The prostatic diseases could also co-exist with other health conditions, commonly referred to as comorbid. ${ }^{2}$ Examples of comorbid diseases include diabetes, high blood pressure, cancer etc. Combinatory therapies also could indirectly have effect on the between prostate cell growth and apoptosis. ${ }^{7}$ Prostate cancer and Benign Prostatic Hyperplasia are also found to form in different areas of the prostate with only $20 \%$ coexisting in the same zone. 8 There is no clear molecular and genetic relationship between PC and BPH and they present 2 distinctive pathogenic pathways. Neither PC nor BPH is a single disease; both are hormonal dependent. ${ }^{9}$ However, both PC and BPH if left untreated develop disease progression since they are progressive diseases.

The current method of treatment for both PC and BPH include modification in lifestyle especially avoiding consumption of highly protein animal related diet, smoking cigarettes and drinking alcohol; device and surgical therapies; pharmaceutical and phytotherapeutic therapies.,10, 11 These methods of treatment have a lot of adverse effects, however, some prove to be less effective. Phytotherapeutic agents have been most commonly used because of their proven potency, availability, cheap and present few or no adverse effects.

Serenoa serrulata (Hook. F.) Michx (syn. S repens [Bartram]) (Arecaceae) is one of the most common phytotherapies used for treatment or management of prostatic diseases. The safety and efficacy of the extracts of $S$. serrulata have been proven both in vitrally and in vivally. This highly rich anti-prostatic plant possesses an inhibitory effect of the 5 - $\alpha$ reductase enzyme, anti-androgenic and estrogenic effect. ${ }^{12}$ However, the anti-prostatic activity of $S$. serrulata have been proven with mixed reports with some manuscripts reporting that its extracts have no significant therapeutic effects even at high dose. ${ }^{13}$

The used of combination therapies are now days on the rise. Combination therapies are commonly preferred to aid in the reduction of the amount of dose of the drugs used, improving on the therapeutic effect of drugs by improving on the activity of the other, minimising the risk of adverse effects as well as provide synergistic

comorbid conditions thus supporting their potency. ${ }^{2}$ The most commonly used combination therapies are between phytotherapies and modern therapy. 
Medicinal plants are used in third world countries for management or treatment of various health conditions including cancer because of their availability or being cheap. Some of these medicinal plants have shown their potency either singly or in combination. $S$. serrulata is one of those medicinal plants highly used for prostatic diseases either singly or in combination with other medicinal plants or even with anti-prostatic conventional drugs. However, there are few reports especially on their combinatory use. Therefore, this review synthesised information on $S$. serrulata's botany, phytochemistry, pharmacology as well as it's used in combination with other medicinal plants and anti-prostatic conventional drugs either clinically or non-clinically.

\section{METHODS}

\section{Literature Review}

The literature was searched from different databases including Medline/PubMed, Cochrane library, Scopus, Proquest library, Embase, EBooks and Google Scholar for relevant records for a period ranging from 1988 to 2021 to identify all published articles on $S$. serrulata regarding treatment of prostatic diseases. The key search terms were Serenoa serrulata, S. repens, Saw palmetto, Prostate cancer treatment with Serenoa serrulata, treatment of Benign Prostatic Hyperplasia with Serenoa serrulata, phytochemicals of Serenoa serrulata, ethno botanical uses of Serenoa serrulata, toxicity of Serenoa serrulata, pharmacological activities of Serenoa serrulata, traditional management and treatment of prostatic diseases using Serenoa serrulata and also clinical trials on treatment of prostatic diseases with Serenoa serrulata. The retrieved articles were reviewed, synthesised and then quantitatively analysed. The reference list of the retrieved articles was also reviewed and synthesised. The original research articles which reported an investigation of $S$. serrulata of any study design, original published research articles, any time of publication and grey literature (conference papers, reported articles, academic thesis) were included. The articles whose full text were not freely available by the time of search and those without clear information about methodology and study were excluded.

\section{RESULTS}

A total of 220 articles were obtained from multiple databases. After a thorough review, a total of 80 articles were excluded because they were not related to the subject matter, 40 articles did not have freely available full text, 35 articles did not have clear research design and methodology and thus 65 were reviewed for this article.

\section{Botany and Description of Serenoa Serrulata.}

Serenoa serrulata (Hook.F.) Michx (syn. S repens [Bartram]) (Arecaceae) commonly known as saw palmetto, sabal, America dwarf palm tree, cabbage palm, fan palm, scrub palm is a rhizomatous plant with fan-shaped leaves and fragrant creamy flowers bearing ovoid blue-black fruits. This medicinal plant is native to South-eastern United States and grows between 3 and 6 feet in height, reaching up to 15 feet. This highly rich medicinal plant grows in sandy soil, producing fruits throughout summer.? The fruit is bluish-black when fully ripe with a distinct sweet aroma, peculiar with a taste that is slightly soapy and acrid. 9 The classification of $S$. serrulata is shown in Table 1 .

\section{TABLE 1: Classification of Serenoa serrulata (Hook. F.) Michx.}

\begin{tabular}{ll}
\hline Family; & Arecaceae \\
\hline Genus; & Serenoa \\
Species; & S. serrulata (Michx) G. Nicholson \\
Scientific name (s); & Serenoa serrulata (Michx) G. Nicholson \\
Synonym (s); & Brahea serrulata, Chamaerops serrulata Michx, Corypha \\
& repens, Sabal serrulata, Sabal serrulatum, Serenoa \\
& repens (W. Bartram) Small, Serenoa serrulata (Michx) \\
& G. Nicholson \\
Common name (s); & American dwarf palm tree, Cabbage palm, Dwarf \\
& palmetto, Fan palm, Fructus Serenoae Repentis, Sabal \\
& fructus, Sabal palm, Saw palmetto, Saw palmetto berry, \\
& Scrub palm, Scrub palmetto, Serenoa
\end{tabular}


Habit;

Habitat;

Propagation;
Shrub tree

Flatwoods, Scrub, Swamps, acidic to alkaline sandy soil

Seeds

\section{Ethnobotanical uses of S. serrulata}

$S$. serrulata is used traditionally in several forms as medicine for many ailments, mostly for treating benign enlargement of the prostate. ${ }^{2}$ The use of $S$. serrulata can be traced back to the 18th century when it was first introduced into the Western medicine practice for prostate related health conditions and other urologic conditions. ${ }^{12}$ It's other uses include; treatment of enlarged prostate, cystitis, gonorrhoea and irritation of the mucous membranes. ${ }^{12}$ Apart from its medicinal uses, some communities use the fruits of S. serrulata as food for nourishment. ${ }^{14}$ The fruits of $S$. serrulata provide it's medicinal properties. These fruits can be used as herbal tea to treat benign enlargement of the prostate, frequent urinary tract infections, enhancing hair growth, reducing cancer cell growth, boosting sexual drive and sperm production in men as well as reducing on the frequent or excessive night urination caused by the inflammation of the bladder or prostate. ${ }^{15}$ It's fruits are also commonly used traditionally as treatment for infertility and underdeveloped breasts in women, increasing lactation and mitigating painful menstruation cycles. ${ }^{9,12}$

\section{Phytochemicals of Serenoa Serrulata and their activities against Prostatic Diseases}

Phytochemicals are biologically active compounds or substances that are produced by plants, the phytochemicals give the plants their therapeutic activities. These chemicals are mainly extracted from the plant material by different solvents depending on the nature of their polarity. Examples of active compounds in the plant extracts include Alkaloids, Fatty acids, Sterols, Steroids, Coumarins, Flavonoids, Anthocyanin, Anthracenoside etc. These phytochemicals have been reported to have anticancer, anti-malarial, anti-bacterial, anti-fungal activities etc. and most of the pharmaceutical drugs in use are derived directly or indirectly from these compounds.

$S$. serrulata is one of the medicinal plants whose berries have been reported to be rich in a number of phytochemicals as shown in Table 2. Phytochemical screening of $S$. serrulata have shown presence of fatty acids, phytosterols and other bioactive components which together contribute to the pharmacological activities of this medicinal plant. ${ }^{9,16}$ The most commonly screened extracts of Serenoa serrulata (Hook. F.) Michx are the hexanic, ethanolic and the supercritical fluid carbondioxide., ${ }^{96}$ Phytochemical screening of $S$. serrulata (Hook. F.) Michx showed that it contains high amounts of free saturated and unsaturated short chained fatty acids and their esters; phytosterols, triglycerides, aliphatic alcohols and various polyprenic acids. ${ }^{9,16}$ The potent phytochemicals of Serenoa serrulata (Hook. F.) Michx, are best extracted with ethanol $90 \%$, hexane and supercritical carbondioxide. ${ }^{9}$ The fatty acids from $S$. serrulata include Lauric acid, oleic acid, Myristic acid and palmitic acid; of which Lauric and oleic acid are the majority and the phytosterols include $\beta$-sitosterol, campesterol, stigmasterol and cycloartenol; of which $\beta$-sitosterol has the highest content. ${ }^{9}$ The fatty acids and phytosterols are collectively responsible for the reduction of the amount of dihydrotestosterone (an active form of testosterone), by blocking conversion of testosterone to dihydrotestosterone and inhibiting the actions of inflammatory substance by suppressing the production of prostaglandins resulting into the prevention of the swelling of the prostate, thus playing an important role in the management and treatment of prostate diseases. ${ }^{13,17,18} \mathrm{~S}$. serrulata is postulated to work by reducing androgenic activity through inhibition of $5-\alpha$ reductase I \& II and inhibition of binding of dihydrotestosterone (DHT) to the cytosolic androgen receptors. S. serrulata also has antiinflammatory activity, anti-proliferative activity and also binds to the receptors existing in the lower urinary tract. ${ }^{19,20}$ The fatty acids are known for inhibiting 5- $\alpha$ reductase only while the phytosterols inhibit 5- $\alpha$ reductase, reduces

prostate tumour growth and ameliorate $\mathrm{BPH}$ symptoms however, none of the phytochemicals of $S$. serrulata is effective alone. ${ }^{13,17,21,22}$

Interestingly, some conventional anti-prostatic drugs also act by inhibiting conversion of testosterone to dihydrotestosterone through inhibition of 5-alpha reductase but some do not inhibit both type 1 and 2 isoenzymes of 5-alpha reductase. ${ }^{23}$ A major undoing is that alpha blockers and 5-alpha reductase inhibitors are associated with major adverse effects like retrograde ejaculation and erectile dysfunction. ${ }^{24,25}$ (Table 2). 
TABLE 2: Phytochemicals of S.serrulata and their activities.

\begin{tabular}{|c|c|c|c|c|}
\hline $\begin{array}{l}\text { Bioactive } \\
\text { component }\end{array}$ & Group & Structure & Activity & Reference \\
\hline $\begin{array}{l}\text { Laurate } \\
\text { (Lauric acid). }\end{array}$ & $\begin{array}{l}\text { saturated } \\
\text { medium- } \\
\text { chain fatty } \\
\text { acid. }\end{array}$ & & $\begin{array}{l}\text {-inhibition of } \\
\text { isoenzymes } \\
\text { ( } 5 \alpha \text { - } \\
\text { reductase } 1 \\
\text { and } 2) \text {. } \\
\text {-inhibition of } \\
\text { prostate } \\
\text { enlargement. } \\
\text {-reduction in } \\
\text { prostate } \\
\text { weight. } \\
\text {-decreases } \\
\text { inflammation } \\
\text { of the } \\
\text { prostate. }\end{array}$ & $28,49,50$ \\
\hline $\begin{array}{l}\text { Myristate } \\
\text { (myristic } \\
\text { acid) }\end{array}$ & $\begin{array}{l}\text { saturated } \\
\text { medium- } \\
\text { chain fatty } \\
\text { acid. }\end{array}$ & un & $\begin{array}{l}\text {-inhibition of } \\
\text { prostate } \\
\text { enlargement. } \\
\text {-reduction in } \\
\text { prostate } \\
\text { weight. } \\
\text {-decreases } \\
\text { inflammation } \\
\text { of the } \\
\text { prostate. }\end{array}$ & $13,49,50$ \\
\hline $\begin{array}{l}\text { Palmitate } \\
\text { (palmitic } \\
\text { acid). }\end{array}$ & fatty acid & 40 & $\begin{array}{l}\text {-decreases } \\
\text { inflammation } \\
\text { of the } \\
\text { prostate. }\end{array}$ & 13 \\
\hline $\begin{array}{l}\text { Stearate } \\
\text { (stearic acid). }\end{array}$ & fatty acid & HO & $\begin{array}{l}\text {-decreases } \\
\text { inflammation } \\
\text { of the } \\
\text { prostate. }\end{array}$ & 13 \\
\hline $\begin{array}{l}\text { Oleate (oleic } \\
\text { acid). }\end{array}$ & fatty acid & & $\begin{array}{l}\text {-inhibition of } \\
5 \alpha \text { - reductase } \\
1 \text {. } \\
\text {-decreases } \\
\text { inflammation } \\
\text { of the } \\
\text { prostate. }\end{array}$ & $13,28,51,52$ \\
\hline
\end{tabular}



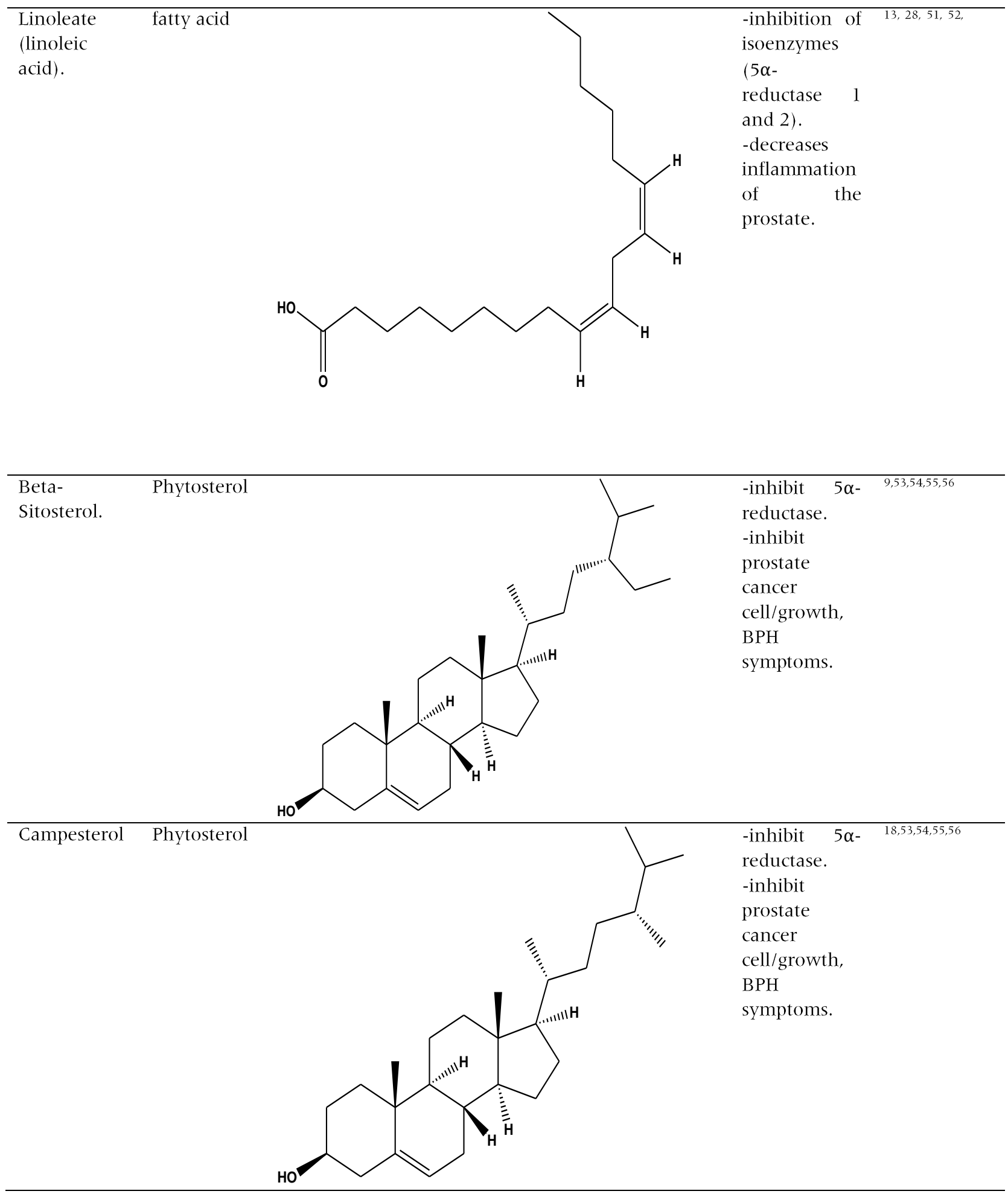


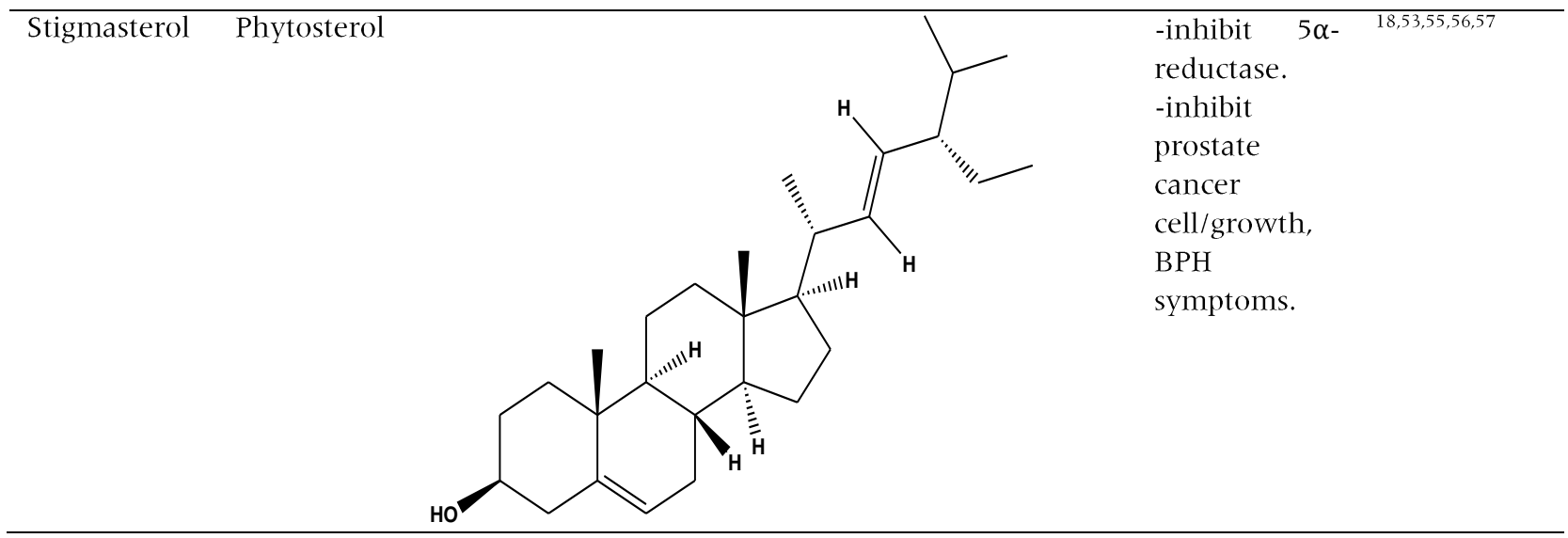

Pharmacological activity of Serenoa serrulata (Hook. F.) Michx. Serenoa serrulata (Hook. F.) Michx have been reported to elicit its anti-prostatic effects through anti-androgenic, anti-inflammatory and proapoptotic, anti-edematous and anti-cancer activities. ${ }^{19,20,26}$ These activities are attributed to the presence of the free fatty acids and the phytosterols. ${ }^{9}, 16,27$

A study by Bayne et al., reported that phytosterols of S. serrulata inhibit both forms of 5-alpha reductase type 1 and 2 iso-enzymes ${ }^{19}$ resulting in an antiandrogenic effect. Most of the synthetic drugs for prostate cancer like Finasteride and Furosteride inhibit only type 2 isoforms. $^{28}$ Finasteride is only a competitive inhibitor of type 25 -alpha reductase ${ }^{26}$ while S. serrulata (Hook. F.) Michx, inhibits both forms of 5-alpha reductase (1\&2) and as well ensures greater control of the activity of the enzyme in the gland. ${ }^{19}$ Dutasteride, a synthetic drug is an inhibitor of both type 1 \& 2 5-alpha reductase ${ }^{28}$ just like the phytosterol of S. serrulata (Hook.F.) Michx. However, S. serrulata (Hook. F.) Michx, does not only inhibit type $18 \quad 2$-alpha reductase, an ant androgenic effect $2^{6}$ but also inhibits the binding of dihydrotestosterone (DHT) to the cytosolic androgen receptors. S. serrulata (Hook. F.) Michx, does not interfere with the cellular capacity of the prostate to secrete Prostate Specific Antigen (PSA) in vitro and in vivo $^{19}$. This offers far much better therapeutic advantage over the other conventional 5 alpha reductase inhibitors since continuous screening and monitoring of the tumour progression in prostate cancer can be carried out through continuous measurement of PSA levels.

An in vivo study conducted using wistar rats in 2000 found out that the phytosterols of $S$. serrulata inhibits both androgenic and prolactin in lateral prostate hyperplasia. ${ }^{29}$ The inhibition of prolactin and growth factor induces cell proliferation. A double blind placebo-controlled clinical study conducted using $S$. serrulata was also found to greatly lower the oestrogen receptors in the nuclear. ${ }^{30}$ S. serrulata administered orally daily in an in vivo experiment using mouse model produced a significant potent antiinflammatory activity. ${ }^{31}$

The phytochemicals of this plant just like other antiprostatic conventional drugs do not interfere with cellular capacity of the prostate in secreting Prostate Specific Antigen (PSA), making it beneficial for continuous screening and monitoring of the tumour progression in prostate cancer by continuous measurement of PSA. ${ }^{19}$ The activities exhibited by these phytochemicals support the potential activity of this plant extract in the management and treatment of prostatic diseases. $^{21,13,22,17}$

\section{Summary of Studies Showing Effects of S. Serrulata on Prostatic Diseases \\ Inhibition of Isoenzymes 1\& 2 Alpha Reductase}

A study conducted by Iehle, C. et al., in 1995 described the independent expression of the type 1 and 2 isoforms of human 5- $\alpha$ reductase and compared the effects of finasteride, turosteride, 4-MA and lipidosterol extract of $S$. repens. The study found out that finasteride and furosteride inhibited type 2 isoforms only but the lipido-sterol extract of $\mathrm{S}$. repens inhibited both type 1 and 2 iso-enzymes. ${ }^{28}$

\section{Inhibition of Prolactin and Growth Factor Induced Cell Proliferation}

It has been established that prolactin and androgens influence the growth and development of prostate gland naturally. ${ }^{29}$ In a study conducted by Van Coppenolle et al., in 2000 using wistar rats to compare 
the effects of lipidosterolic extract of S. repens and finasteride both of which are 5 - $\alpha$ reductase inhibitors, the lipidosterolic extract of $S$. repens was found to inhibit both androgenic and prolactin in lateral prostate hyperplasia while the finasteride only inhibited the effect of androgens on prostate enlargement. ${ }^{29}$

\section{Antiestrogen Effects}

A double blind placebo-controlled clinical study conducted by Silverio, F. et al., in 1992 using 35 BPH patients who had never been on any treatment, showed that the estrogen receptors in the nuclear were significantly lowered in groups treated with the extracts of S. repens than those which were not treated with $S$. repens. ${ }^{32}$

\section{Anti-inflammatory effects}

In an in vivo experiment conducted by Bernichtein, S. et al., in 1995 using unique pro-inflammatory mouse model of prostate hyperplasia with Permixon- a hexanic lipidosterolic extract of $\mathrm{S}$. repens orally administered daily at a dose of $100 \mathrm{mg} / \mathrm{kg}$ for 28 days, there was a significant potent anti-inflammatory activity in the group that were given the extract when compared to the group that were not. ${ }^{31}$

\section{Toxicity of Serenoa Serrulata}

There are a number of preparations from dried berries of $S$. serrulata in the market. The most commonly available, used and highly investigated remedy, clinically and non-clinically with most published reports on the toxicity profile of $S$. serrulata is Permixon (French Producer Pierre Fabre Medicament). ${ }^{33}$ Permixon is a hexane lipidosterolic extract of the berries of $S$. serrulata. ${ }^{33}$ The adverse effects of extracts of berries of $S$. serrulata are abdominal pain, diarrheal, nausea, fatigue, headache, rhinitis and decreased libido which are all mild, infrequent and reversible. ${ }^{21,13,22,17}$ A clinical trial study conducted in 1997 on 132 patients suffering from Benign prostatic hyperplasia to determine the efficacy and safety of 2 dosage forms (160 mg b.i.d and $320 \mathrm{mg}$ o.d) of the extract of Serenoa repens concluded that the extracts of the 2 dosage forms were safe and efficacious. $^{34}$ Meanwhile in an in vitro study to investigate the hepatotoxicity potential of saw palmetto in rats' liver function, it was reported that the extracts of saw palmetto exhibited no toxic effect on the laboratory animal. ${ }^{35}$ Furthermore, an in vivo experiment to assess the tolerability and toxicity of lipidosterolic extract of America dwarf palm Serenoa repens in wistar rats concluded that there was no toxicological effect of the preparations in the experimental animals. ${ }^{33}$

Combination of $S$. Serrulata with other Medicinal Plants for the Treatment/Management of Prostatic Diseases

Combination therapy is an important treatment modality in many disease settings including cancer, cardio-vascular disease and infectious diseases. ${ }^{36}$ Polyherbal formulation is a common practice for exploiting the advantage of synergistic interaction for enhanced therapeutic efficacy. ${ }^{36}$ Many chronic conditions have been treated with combination therapy for many years based on the phenomenon of resistance. ${ }^{37}$ Resistance arises when an organism gains the ability to resist a drug which initially effectively slowed the growth or even killed the target organism. Treatment with a combined therapy reduces the chance of resistance especially if the 2 drugs have different mechanisms of reducing the organism's normal functions. ${ }^{38}$ Combining drugs enhance the efficacy, minimises the adverse effects of drugs, improved therapeutic value, dose and toxicity reduction as well as to minimising or delaying the induction of drug resistance. Toxicity reduction and resistance minimisation benefits could also be the outcomes of synergism. ${ }^{38,36,39}$ The 2 drug combinations might have effect on either one another or on the organism.

When drugs are combined, there are 3 possible effects: First is they act independently of one another, Secondly they increase each other's effect; this could happen because they affect the body in the same way or because one drug increases the concentration of the other in the body and thirdly, they decrease each other's intended effects; this could occur when one drug blocks or prevents another drug from working (combination-drugs). ${ }^{36,39}$

Phytotherapies comprise of many active constituents which enhance their activity synergistically. The effects of many constituents found in herbal medicinal products and their extracts are mainly explained by the term synergy and polyvalence especially when it is difficult to distinguish the active ingredient. ${ }^{39}$ Drug synergy occurs when drugs interact in ways that enhance or magnify one or more effects or side effects of the drugs. ${ }^{39}$ Synergy is used in a positive sense, that is, an increase in effect greater than that predicted. However, an unexpected decrease in activity referred to as negative synergy or antagonism may occur particularly in interactions between some modern medicines and herbal products. ${ }^{39,40}$ Synergy often occurs when an extract of a plant gives a greater or 
safer response than an equivalent dose of the compound considered to be the active one. ${ }^{41,42}$ The choice of treatment or management methods of prostatic diseases have always been the use of a combination of therapies to prevent the spread to other places. The treatment modalities are radical prostatectomy for the localised tumours, radical radiotherapy and androgen deprivation therapy for non-confined tumours. ${ }^{43,44}$ The presence of comorbidities which are highly prevalent among these patients are also some of the factors for the combination therapies. Comorbidities which contribute to the increase in mortality rates among the prostatic patients need to be managed through combination therapies because monotherapies treat or manage only one condition and yet a factor contributing to the death of the patient could be from the comorbidities. ${ }^{45}$

The rationale for combinatory treatment is to use drugs that work by different mechanism thus decreasing the possibility of building resistance. When drugs with different effects are combined, each drug can be used at its optimal dose without intolerable side effects. A combinatory treatment also reduces disease symptoms and prolongs life. Combination therapy can be between modern therapies, modern therapy with phytotherapy or between phytotherapies only. In this review, the combinatory therapies showed a better synergy, improvement in the quality of life and as well reduction in the adverse effects especially of the conventional drugs. The conventional drugs used in combination with $S$. serrulata in studies reported in this review include Finasteride and Tamsulosin while the medicinal plants reported include Stinging Nettle (Urtica dioca), Zingiber officinalis, Echinacea angustifolia and Pumpkin (Cucurbita pepo). The isolated compounds reported include $\beta$-sitosterol, Vitamin E, lycopene and Selenium; the extract of pollen grain- Cernitin. Finasteride is an anti-prostatic conventional drug which acts by inhibiting type 2 5- $\alpha$ reductase, a similar mechanism exhibited by $S$. serrulata, however, $S$. serrulata inhibits both type 1 and 2 isoforms of 5- $\alpha$ reductase; a mechanism which complements the other. The summary of studies showing combination between phytotherapies alone and then phytotherapies with conventional drug is shown in Table 2. The combinatory therapy has exhibited high efficacy on prostatitis diseases as compared to monotherapies. This is shown in the Table 3. The synergistic effect shown by the combinations as presented in Table 3 proved to be better than the conventional monotherapy alone.

TABLE 3: Combination of S. serrulata with other medicinal plants

\begin{tabular}{|c|c|c|c|c|c|}
\hline Study design & Combination & $\begin{array}{l}\text { Prostatic } \\
\text { disease }\end{array}$ & Observations & Conclusion & References \\
\hline $\begin{array}{l}\text { Randomized- } \\
\text { controlled - } \\
\text { double blind- } \\
\text { placebo }\end{array}$ & $\begin{array}{l}\text {-Cernitin } \\
\text { (collection of } \\
\text { pollens) } \\
\text {-Saw palmetto } \\
\text { (S. serrulata or } \\
\text { S. repens) } \\
\text {-Beta Sitosterol } \\
\text {-Vitamin E } \\
\text { (antioxidant) }\end{array}$ & $-\mathrm{BPH}$ & $\begin{array}{l}\text { - the } \\
\text { combination } \\
\text { exhibited a } \\
\text { decreased in the } \\
\text { overall symptoms } \\
\text { of BPH like } \\
\text { Nocturia and } \\
\text { frequency of } \\
\text { urination. } \\
\text { - the } \\
\text { monotherapies } \\
\text { exhibited very } \\
\text { small change in } \\
\text { the PSA } \\
\text { measurement, } \\
\text { maximal and } \\
\text { average urinary } \\
\text { flow rates and } \\
\text { residual volume } \\
\text { which was not } \\
\text { significant. }\end{array}$ & $\begin{array}{l}\text {-There was a general } \\
\text { improvement in the } \\
\text { symptoms of BPH with } \\
\text { the combination } \\
\text { compared to the } \\
\text { monotherapy and the } \\
\text { placebo. }\end{array}$ & 58 \\
\hline
\end{tabular}




\begin{tabular}{|c|c|c|c|c|c|}
\hline & & & $\begin{array}{l}\text {-The combination } \\
\text { test group had no } \\
\text { adverse effect. }\end{array}$ & & \\
\hline In vivo study & $\begin{array}{l}\text {-Saw palmetto } \\
\text { (extract and } \\
\text { whole berry) } \\
\text {-Cernitin }\end{array}$ & $\begin{array}{l}\text {-Prostate } \\
\text { growth }\end{array}$ & $\begin{array}{l}\text {-The prostate size } \\
\text { Reduced in all } \\
\text { the treatment to } \\
\text { the same size as } \\
\text { the non-castrated } \\
\text { rat. } \\
\text {-the body weight } \\
\text { reduced in all the } \\
\text { treatment group } \\
\text { too. }\end{array}$ & $\begin{array}{l}\text {-significant reduction in } \\
\text { the prostate size in all } \\
\text { the treatment. } \\
\text {-combination of Saw } \\
\text { palmetto and Cernitin } \\
\text { influences prostatic } \\
\text { hyperplasia through the } \\
\text { effects on androgen } \\
\text { metabolism. }\end{array}$ & 59 \\
\hline $\begin{array}{l}\text { Randomized, } \\
\text { double blind, } \\
\text { placebo } \\
\text { controlled trials } \\
\text { clinical study }\end{array}$ & $\begin{array}{l}\text {-Pumpkin seed } \\
\text { oil } \\
\text {-Saw palmetto } \\
\text { oil }\end{array}$ & -BPH & $\begin{array}{l}\text {-There was a } \\
\text { little } \\
\text { Improvement of } \\
\text { Quality of Life in } \\
\text { the saw palmetto } \\
\text { oil group but } \\
\text { much higher in } \\
\text { the combination } \\
\text { group within a } \\
\text { short period of } \\
\text { about 6months. } \\
\text {-The PSA level } \\
\text { was reduced in } \\
\text { the saw palmetto } \\
\text { oil group after } 3 \\
\text { months. } \\
\text {-All the group } \\
\text { treatment had no } \\
\text { improvement in } \\
\text { prostate volume. } \\
\text {-Maximal urinary } \\
\text { flow rate had } \\
\text { great } \\
\text { improvement in } \\
\text { saw palmetto and } \\
\text { pumpkin seed oil } \\
\text { group. }\end{array}$ & $\begin{array}{l}\text {-Combination of saw } \\
\text { palmetto and pumpkin } \\
\text { seed oil had an } \\
\text { insignificant } \\
\text { improvement in all the } \\
\text { parameters though its } \\
\text { effect was higher } \\
\text { symptomatically. } \\
\text {-The combination was } \\
\text { clinically safe. } \\
\text {-Recommends the used } \\
\text { of the combination for } \\
\text { BPH. }\end{array}$ & 60 \\
\hline $\begin{array}{l}\text { Randomized } \\
\text { double blinded } \\
\text { clinical study }\end{array}$ & $\begin{array}{l}\text {-Serenoa repens } \\
\text {-Lycopene and } \\
\text { selenium } \\
\text {-Tamsulosin }\end{array}$ & $\begin{array}{l}-\mathrm{BPH} \\
\text {-LUTS }\end{array}$ & $\begin{array}{l}\text {-Much higher } \\
\text { significant } \\
\text { improvement in } \\
\text { the combination } \\
\text { therapy. } \\
\text {-Increase in } \\
\text { Qmax. } \\
\text {-Changes in IPSS } \\
\text { and Qmax was } \\
\text { greater for the } \\
\text { combination than }\end{array}$ & $\begin{array}{l}\text {-Combination was more } \\
\text { effective than single } \\
\text { therapies in improving } \\
\text { IPSS and increasing } \\
\text { Qmax in patients with } \\
\text { LUTS. }\end{array}$ & 61 \\
\hline
\end{tabular}




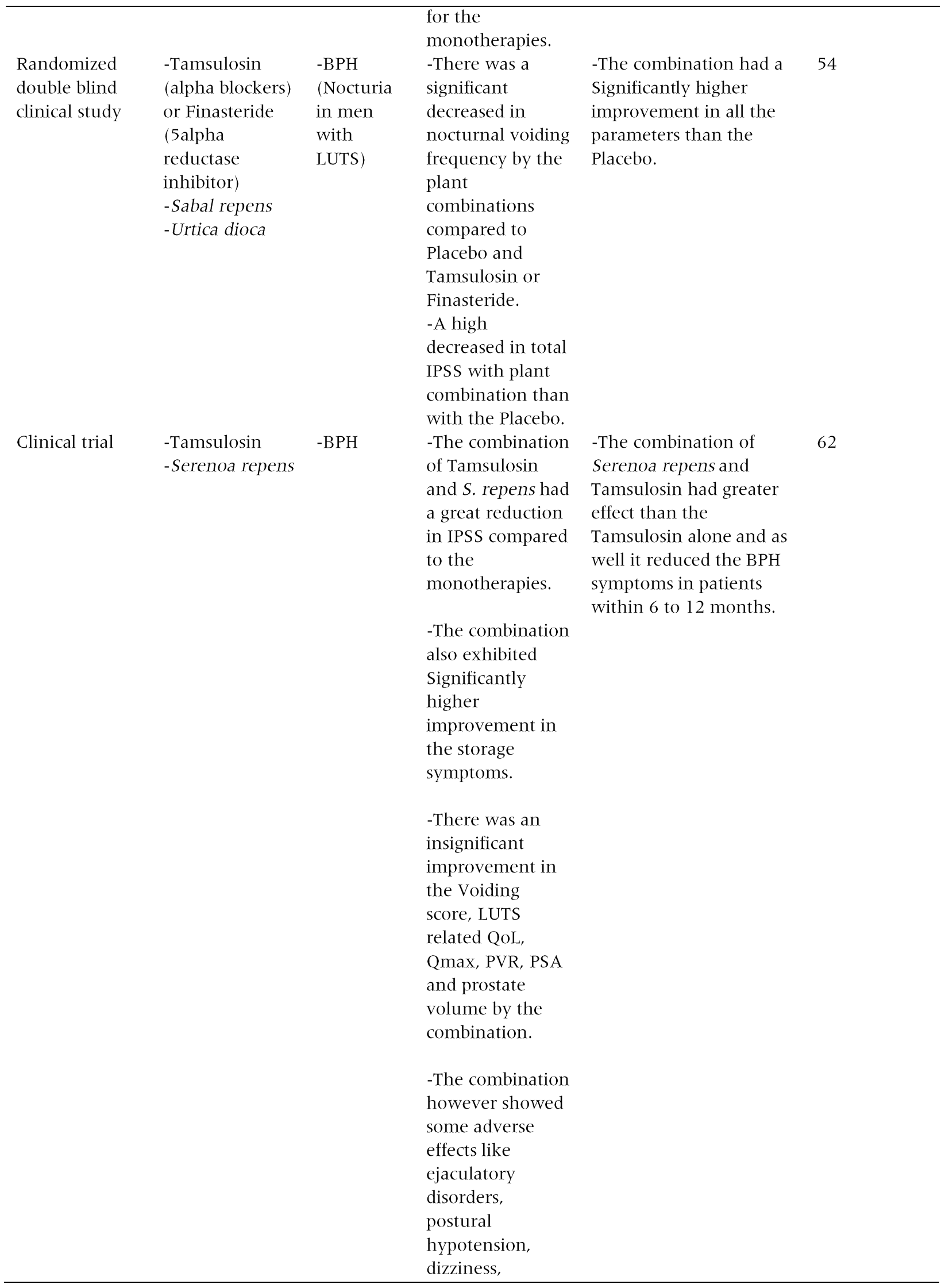




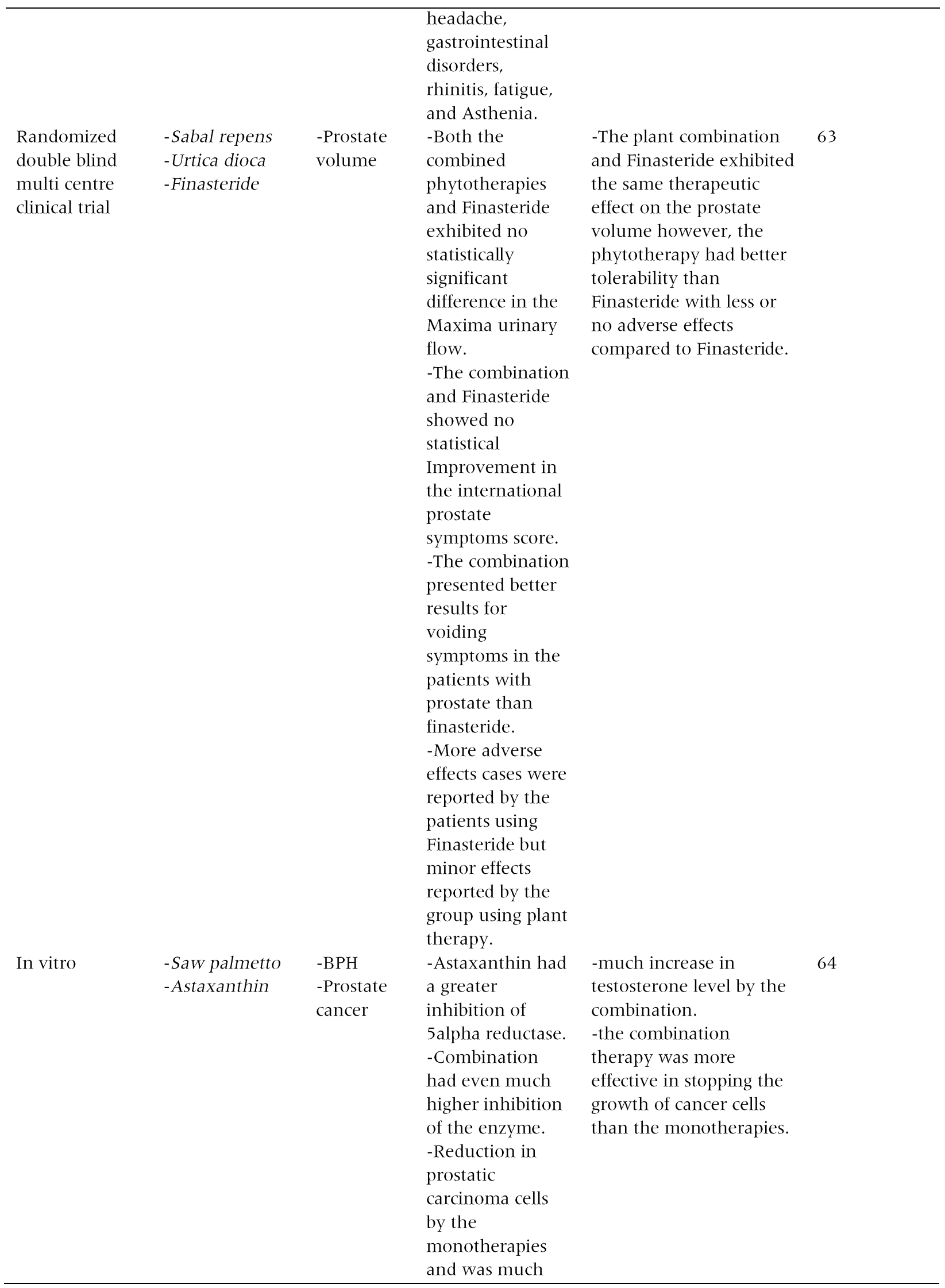




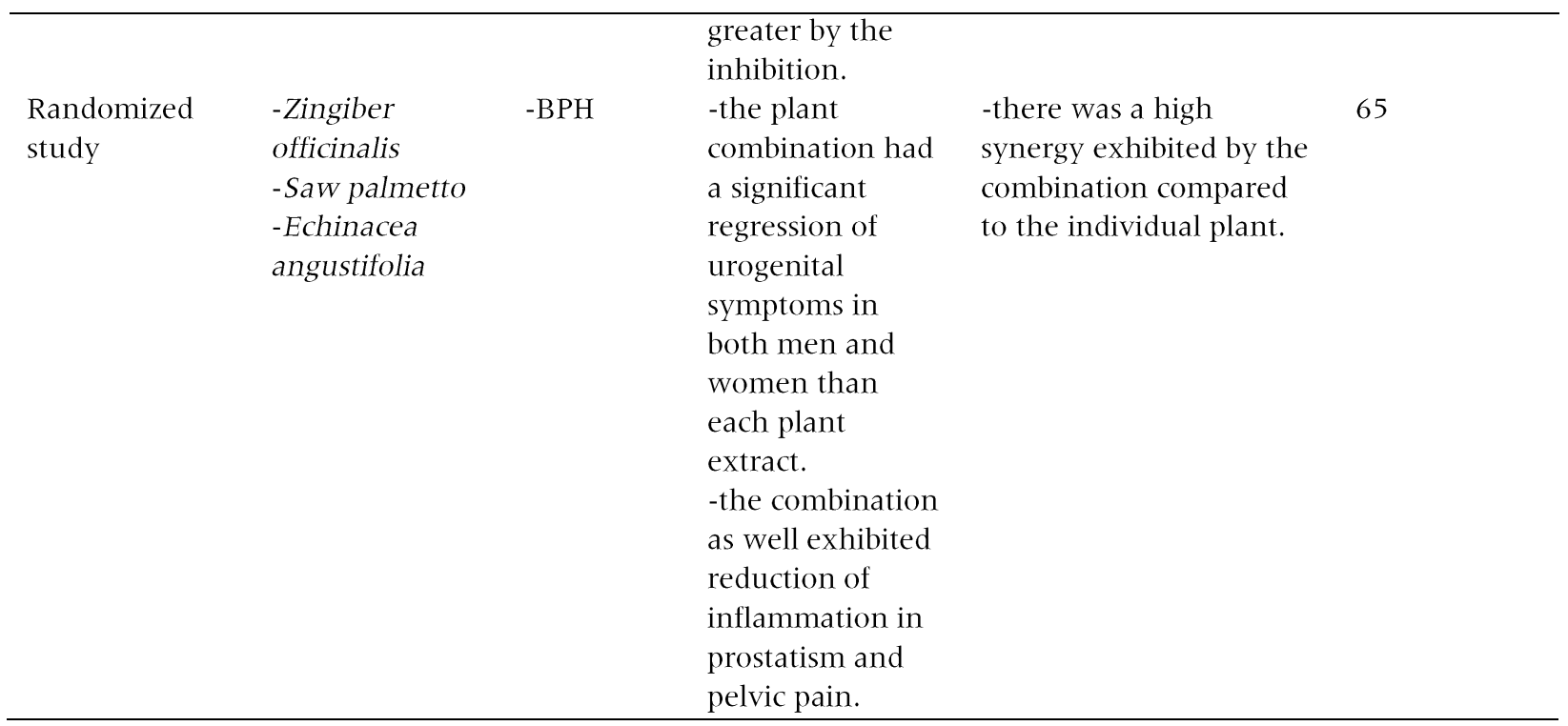

\section{DISCUSSION}

Prostatic diseases include prostate cancer, prostatitis and benign prostatic hyperplasia. Prostate cancer and Benign Prostatic Hyperplasia are still common condition affecting men especially of older age while prostatitis affect men as young as 35 years mainly due to infections. There are quite a number of treatment options being used and most of them present adverse effects while others are not very effective even at higher doses which are not pleasant to the end user. ${ }^{46}$ Medicinal plants have been used for decades for treatment or management of different ailments including prostatic diseases. ${ }^{47}$ One of the medicinal plants used for treatment or management of prostatic diseases is $S$. serrulata. Both clinical and non-clinical studies have proven the used of $S$. serrulata either singly or in combination with anti-prostatic conventional drugs or with other medicinal plants.

The phytochemical and the pharmacological results for the investigation of $S$. serrulata as an antiprostatic remedy is in agreement with the ethnobotanical claims as shown in Tables 1 and 2 . The plant toxicity profile is also in agreement with its ethnobotanical claims. This medicinal plant when used in combination is proven to enhance its activity. Table 3, further points out the synergistic effect of the combination of $S$. serrulata with other medicinal plants and even with conventional drug presenting minimal or no adverse effect compared to the conventional drugs Tamsulosin or Finasteride used alone. This study found out that the medicinal plants which are used in combination with $S$. serrulata include; Urtica dioca, Cucurbita pepo, Zingiber officinalis and Echinacea angustifolia and then the anti-prostatic conventional drugs include; Finasteride and Tamsulosin. This finding could also explain the variations in efficacy reported by some studies during the determination of the anti-prostatic activities of $S$. serrulata. ${ }^{8}$ The review also noted that most of these studies were clinical, few were in vivo and the review didn't come across any in vitro study.

\section{CONCLUSION AND RECOMMENDATION}

This review has shown that $S$. serrulata is used as a remedy for different ailments but most commonly used for prostatic diseases with less or no adverse toxic effects. This medicinal plant has also shown a great potential when used as an anti-prostatic remedy when used in combination. $S$. serrulata has vital phytochemicals with promising pharmacological activities which could be developed into well standardised drugs either as a single plant or in their combinations with other medicinal plants. There is however need to investigate further their effects and safety on prostatic conditions when used in combination with other medicinal plants which might not have been mentioned here but have been reported to have anti-prostatic activities.

\section{REFERENCES}

1. Prostatic Diseases. Basic facts and Informations. HealthinAging.org. 2019; (Accessed March 2019). https://www.healthinaging.or/aging-and-health-a-toz/topic:prostate-diseases/.

2. Kevin T McVary. BPH: Epidemiology and Comorbidities. Supplements and Featured Publications, BPH and Comorbid Conditions: Optimizing Treatment for the Aging Man. Am J Manag Care. 2006;12(5):2288.

3. Lim K Bin. Science Direct Epidemiology of clinical benign prostatic hyperplasia. Asian J Urol. 2017;4(3):148-151. doi:10.1016/j.ajur.2017.06.004

4. Antonio Alcaraz 1, Peter Hammerer, Andrea Tubaro, Fritz H 
Schröder RC. Is There Evidence of a Relationship between Benign Prostatic Hyperplasia and Prostate Cancer? Findings of a Literature Review. Eur Urol. 2009;55(4):864-873. doi:10.1016/j.eururo.2008.11.011

5. Cancer Today . Lyon - Global Cancer Observatory - Available from: b. IARC-International Agency Res Cancer. 2021; (Accessed 24th March 2021). ttps://gco.iarc.fr/today/ .

6. Bray F, Ferlay J, Soerjomataram I. Global Cancer Statistics 2018: GLOBOCAN Estimates of Incidence and Mortality Worldwide for 36 Cancers in 185 Countries. CA CANCER J CLIN. 2018;68:394-424. doi:10.3322/caac.21492

7. Mottet N, Bellmunt J, Representative EBP, et al. Guidelines on Prostate Cancer. Eur Assoc Urol. 2016. https://uroweb.org/wpcontent/uploads/09-Prostate-Cancer_LR.pdf.

8. John E. McNeal. Normal Histology of the Prostate. Am J Surg Pathol. 1988;12(8):619-633. doi:10.1097/00000478198808000-00003

9. Kerry B, Simon M. Principles and Practice of Phytotherapy: Modern Herbal Medicine. In: Modern Herbal Medicine. Churchill Livingstone; 2013:804-817.

10. Claus G. Roehrborn. Benign Prostatic Hyperplasia: An Overview. Rev Urol. 2005;7(9):3-14

11. Oesterling E Joseph. Benign Prostatic Hyperplasia: Medical and Minimally Invasive Treatment Options. $N$ Engl $\mathrm{J}$ Med. 1995;332:99-109.

12. Historical Use of Saw Palmetto. Aphios Heal Wellness Center. 2018; (Accessed November 2018). www.aphioshwe.com/products/speroltm-ds-detail/historicaluse-of-saw-palmetto.html.

13. Suzuki $M$, Ito $Y$, Fujino $T$, Abe $M$, Umegaki $K$, Onoue $S$. Pharmacological effects of saw palmetto extract in the lower urinary tract. Acta Pharmacol Sin. 2009;30(3):271-281. doi: 10.1038/aps.2009.1

14. Saw Palmetto. Drugs com. be sure. know more. 2021;(Accessed 24th March 2021)

15. Saw Palmetto Uses and Benefits as a Medicinal Herb. Therapeutic Uses, Benefits and Claims of Saw Palmetto. Herb Source. 2019; (Accessed October 2019).

16. Plosker GL, Brogden RN. Serenoa repens ( Permixon ®) ). Drugs Aging. 1996;9(5):379-395. DOI: 10.2165/00002512199609050-00008

17. Nyamai DW, Mawia AM, Wambua FK, Njoroge A, Matheri F , Lagat R, Kiambi J , Ogola P, Arika W, Cheseto X, King'ori E, Ramni J , Ngugi MP, Muchugi A, Ng'ang'a M , Burugu MW. Products Phytochemical Profile of Prunus africana Stem Bark from Kenya. J Pharmagnosy Nat Prod. 2015;1(1):1-8. doi: 10.4172/2472-0992.1000110

18. Holtz RL Von, Fink CS, Awad AB, Holtz RL Von, Fink CS, Awad AB. $\beta$ - sitosterol activates the sphingomyelin cycle and induces apoptosis in LNCaP human prostate cancer cells. Nutr Cancer. 2009:32(1):8-12. http://dx.doi.org/10.1080/01635589809514709 PLEASE.

19. Bayne CW, Donnelly F, Ross M, Habib FK. Serenoa repens ( Permixon $\circ$ ): A $5 \sqcup$-Reductase Types I and II Inhibitor New Evidence in a Coculture Model of BPH. Prostate. 1999;40:232-241. doi:DOI: 10.1002/(sici) 10970045(19990901)40:4<232::aid-pros4>3.0.co;2-0

20. Gato DI, Carsten T, Vesterlund M, Pousette A, Schoop R. Androgen - independent Effects of Serenoa repens Extract Prostasan (B) on Prostatic Epithelial Cell Proliferation and In fl

34. Wistar rats: well-known extract, new insight. Eur Rev Med Pharmacol Sci. 2011;15:1311-1317.

35. Braeckman J, Bruhwyler J, Vandekerckhove K, Géczy J. Efficacy and Safety of the Extract of Serenoa repens in the Treatment of Benign Prostatic Hyperplasia: Therapeutic Equivalence Between Twice and Once Daily Dosage Forms. Phyther Res. 1997:11(June):558-563.

36. Singh YN, Devkota AK, Sneeden DC, Singh KK, Halaweish F. Hepatotoxicity potential of Saw Palmetto (Serenoa repens) in rats. Phytomedicine. 2007;14:204-208. doi:10.1016/j.phymed.2006.03.024

37. Rasoanaivo P, Wright CW, Willcox ML, Gilbert B. Whole plant extracts versus single compounds for the treatment of malaria : synergy and positive interactions. Malar J. 2011;10(Supp 1):S4. doi:10.1186/1475-2875-10-S1-S4

38. Ascierto PA, Marincola FM. Combination therapy: the next opportunity and challenge of medicine. J Transl Med. 2011;9(1):115. doi:10.1186/1479-5876-9-115

39. Worthington RJ, Melander C. Combination approaches to ammation. Phyther Res. 2011;264:259-264. doi:DOI: $10.1002 /$ ptr. 3537

21. Liang $\mathrm{T}$, Liao $\mathrm{S}$. Inhibition of steroid $5 x$-reductase by specific aliphatic unsaturated fatty acids. Biochem J. 1992;285:557562. doi: $10.1042 / \mathrm{bj} 2850557$

22. Goldenberg L, Alan S, Fleshner N, Rendon R, Drachenberg D, Elhilali $\mathrm{M}$. The role of 5-alpha reductase inhibitors in prostate pathophysiology: Is there an additional advantage to inhibition of type 1 isoenzyme? Can Urol Assoc J. 2009:3(3):109-114.

23. Gacci M, Eardley I, Giuliano F, et al. Critical Analysis of the Relationship Between Sexual Dysfunctions and Lower Urinary Tract Symptoms Due to Benign Prostatic Hyperplasia. Eur Urol. 2011:60(4):809-825. doi:10.1016/j.eururo.2011.06.037

24. Dixon CM, Kusek JW, Ph D, et al. The Long-Term Effect of Doxazosin, Finasteride, and Combination Therapy on the Clinical Progression of Benign Prostatic Hyperplasia. . N Engl J Med. 2003;349(25).

25. Kapoor A. Benign prostatic hyperplasia ( BPH ) management in the primary care setting. October 201219 Suppl 1: 10-7. Can J Urol. 2012;1 (10-7).

26. Ioanel Sinescu, Petrisor Geavlete, Razvan Multescu, Constantin Gangu, Florin Miclea, Ioan Coman, Ioan Ioiart, Valentin Ambert, Traian Constantin, Bogdan Petrut, Bogdan Feciche. Long-Term Efficacy of Serenoa repens Treatment in Patients with Mild and Moderate Symptomatic Benign Prostatic Hyperplasia. Urol Int. 2011;86:284-289. doi:10.1159/000322645

27. Comhaire F, Mahmoud A. Preventing diseases of the prostate in the elderly using hormones and nutriceuticals. Aging Male. 2004:7:155-169. doi:10.1080/13685530412331284722

28. Catherine Iehle, Sylvie Delos, Olivier Guirou, Rothwell Tate, Jean-Pierre Raynaud and Pierre-Marie Martin . Human Prostatic Steroid $5 \alpha$-Reductase Isoforms. A C o m p a r a t i v e S t u d y of S e l e c t i v e Inhibitors. J Steroid Biochem Molec Biol. 1995;54(5):273-279. doi:DOI: 10.1016/09600760(95)00134-1

29. Coppenolle F Van, Bourhis X Le, Delaby G, et al. Pharmacological Effects of the Lipidosterolic Extract of Serenoa repens ( Permixon m ) on Rat Prostate Hyperplasia Induced by Hyperprolactinemia: Comparison With Finasteride. Prostate. 2000;43 (November 1999):49-58. doi:DOI: 10.1002/(sici) 10970045(20000401)43:1<49::aid-pros7>3.0.co; 2 -j

30. Di Silverio F, Monti S, Sciarra A, et al. Effects of Long-Term Treatment With Serenoa repens ( Permixon on ) on the Concentrations and Regional Distribution of Androgens and Prostatic Hyperplasia. Prostate. 1998:37:77-83. doi:DOI: 10.1002/(sici) 1097-0045(19981001)37:2<77::aidpros $3>3.0 . c 0 ; 2-i$

31. Bernichtein S, Pigat N, Camparo P, Latil A. Anti-Inflammatory Properties of Lipidosterolic Extract of Serenoa Repens ( Permixon W , in a Mouse Model of Prostate Hyperplasia. Prostate. 2015:75:706-722. doi:10.1002/pros.22953

32. Di Silverio F, D'Eramo G, Flammia G P, Sciarra A, Palma E, Caponera M SF. Evidence that Serenoa repens extract displays an antiestrogenic activity in prostatic tissue of benign prostatic hypertrophy. Eur Urol. 1992:21(4):1281103.

33. DUBORIJA-KOVACEVIC1 N, , V. JAKOVLJEVIC2, A. SABO2 , Z. TOMIC2, B. PAJOVIC3 DP. Tolerability and toxicity of lipidosterolic extract of american dwarf palm Serenoa repens in combat multidrug-resistant bacteria. Trends Biotechnol. 2013;31(3):179-186. doi:10.1016/j.tibtech.2012.12.006

40. Houghton P. Synergy and polyvalence: paradigms to explain the activity of herbal products. Eval Herb Med Prod Pharm Press. 2009.

41. Abebe W. Herbal medication : potential for adverse interactions with analgesic drugs . J Clin Pharm Ther. 2002;27(6):391-401.

42. Baker D, Pryce G, Baker D, et al. Cannabinoids control spasticity and tremor in a MS model Cannabinoids control spasticity and tremor in a multiple sclerosis model. Nature. 2000;404. doi:10.1038/35003583

43. Williamson EM. Synergy and other interactions in phytomedicines. 2001;8(5):401-409.

44. Anna Bill-Axelson, Lars Holmberg, Hans Garmo, Jennifer R. Rider, Sc.D., Kimmo Taari, Christer Busch, Stig Nordling, Michael Häggman, Swen-Olof Andersson, Ove Andrén, Juni Palmgren, Gunnar Steineck, Hans-Olov Adami, and Jan-Erik Johansson. Radical Prostatectomy or Watchful Waiting in Early Prostate Cancer. N Engl J Med. 2014. 
doi:10.1056/NEJMoa1311593

45. Timothy J. Wilt, M.D., Michael K. Brawer, Karen M. Jones, Michael J. Barry, William J. Aronson, Steven Fox, Jeffrey R. Gingrich, John T. Wei, Patricia Gilhooly, Mayer Grob, Imad Nsouli, Padmini Iyer, Ruben Cartagena, Glenn Snider, Claus Roehrborn, Roohollah Sharifi, William Blank, Parikshit Pandya, Gerald L. Andriole, Daniel Culkin, and Thomas Wheeler. Radical Prostatectomy versus observation for Localized Prostate Cancer Timothy. N Engl J Med. 2012;367(3). doi:10.1056/NEJMoa1113162

46. Lee L, Cheung WY, Atkinson E, Krzyzanowska MK. Impact of Comorbidity on Chemotherapy Use and Outcomes in Solid Tumors: A Systematic Review. J Clin Oncol. 2011;29(1). doi: $10.1200 /$ JCO.2010.31.3049

47. NCCN Guidelines for Patients ®. Prostate Cancer. Natl Compr symptoms in animal model. African J Pharm Pharmacol. 2016;10(8):101-106. doi:10.5897/AJPP2012.1533

52. Weisser H, Tunn S, Behnke B, Krieg M. Effects of the Sabal serrulata Extract IDS 89 and I t s Subfractions on 5aIReductase Activity in Human Benign Prostatic Hyperplasia. Prostate. 1996;28:300-306. doi:DOI: 10.1002/(SICI) 10970045(199605) 28:5<300::AID-PROS5>3.0.CO;2-F

53. Palin M, Faguy M, Lehoux J, Pelletier G. Inhibitory Effects of Serenoa repens on the Kinetic of Pig Prostatic Microsomal $5 \alpha$ -Reductase Activity. Endocrine. 1998;1(1):65-69.

54. Awad AB, Fink CS, Williams H, Kim U. In "itro and in " i " o ž SCID mice / effects of phytosterols on the growth and dissemination of human prostate cancer PC-3 cells. Eur J Cancer Prev. 2001;10:507-513. doi:DOI: 10.1097/00008469200112000-00005

55. Oelke M, Berges R, Schläfke S. Fixed - dose combination PRO $160 / 120$ of sabal and urtica extracts improves nocturia in men with LUTS suggestive of BPH : re - evaluation of four controlled clinical studies. World J Urol. 2014. doi:10.1007/s00345-0141338-X

56. Cabeza M, Bratoeff E, Heuze I, Ramírez E, Sánchez M, Flores E. Effect of beta-sitosterol as inhibitor of 5 alpha-reductase in hamster prostate. Proc West Pharmacol Soc. 2003;46:153-155.

57. Sharma KP, Sharma PC, Scholtysek C, Krukiewicz AA Goldmann WH. Biochemical and Biophysical Research Communications Characterizing components of the Saw Palmetto Berry Extract ( SPBE) on prostate cancer cell growth and traction. Biochem Biophys Res Commun. 2009;379:795798. doi:10.1016/j.bbrc.2008.11.114

58. Berges R R, Windeler J, Trampisch H J, TS and the sbgr; sitosterol study group*. Randomised, placebo-controlled, double-blind clinical trial of Ebgr;-sitosterol in patients with benign prostatic hyperplasia. Lancet. 1995;345:1529-1532 doi:DOI: 10.1016/s0140-6736(95)91085-9

59. Preuss HG, Marcusen C, Regan J, Klimberg IW, Welebir TA Jones WA. Randomized trial of a combination of natural products ( cernitin, saw palmetto, B-sitosterol, vitamin E) on symptoms of benign prostatic hyperplasia ( BPH ). Int Urol Nephrol. 2001:33:217-225. doi:DOI: 10.1023/a:1015227604041

60. Talpur N, Echard B, Bagchi D, Bagchi M, Preuss HG Comparison of Saw Palmetto ( extract and whole berry) and Cernitin on prostate growth in rats. Mol Cell Biochem. 2003; (250):21-26.

61. Hong H, Kim C, Maeng S. Effects of pumpkin seed oil and saw palmetto oil in Korean men with symptomatic benign prostatic hyperplasia. Nutr Res Pract. 2009;3(4):323-327. doi:10.4162/nrp.2009.3.4.323

62. Morgia G, Russo GI, Voce S, et al. Serenoa Repens, Lycopene and eleniumVersusT amsulosin for theT reatment of LUTS / $\mathrm{BPH}$. An Italian Multicenter Double-Blinded Randomized Study Between Single or CombinationTherapy ( PROCOMB T rial ). Prostate. 2014;74:1471-1480. doi:10.1002/pros.22866

63. Woo Y, Song R, Lim W, Hoon J, Seung K, Ahn H. Comparison of Tamsulosin Plus Serenoa Repens with Tamsulosin in the Treatment of Benign Prostatic Hyperplasia in Korean Men: 1Year Randomized Open Label Study. Urol Int. 2015. doi:10.1159/000366521

64. SOKELAND J. Combined sabal and urtica extract compared with (B) nasteride in men with benign prostatic hyperplasia: analysis of prostate volume and therapeutic outcome. BJU Int. 2000;86:439-442. doi:DOI: $10.1046 / j .1464-$ $410 x .2000 .00776 . x$

65. Anderson ML. of the Enzymatic Inhibition of $5 \alpha$-Reductase
Cancer Network, Inc. 2014;1. NCCN.org/patients.

48. Mahomoodally MF. Traditional Medicines in Africa: An Appraisal of Ten Potent African Medicinal Plants. Evid Based Complement Altern Med. 2013;2013.

49. Penugonda K, Lindshield BL. Fatty Acid and Phytosterol Content of Commercial Saw Palmetto Supplements. Nutrients. 2013; (May). doi:10.3390/nu5093617

50. Babu SVV, Veeresh B, Patil AA, Warke YB. Lauric acid and myristic acid prevent testosterone induced prostatic hyperplasia in rats. Eur J Pharmacol. 2010;626(2-3):262-265. doi:10.1016/j.ejphar.2009.09.037

51. Patil AA, Yadav, Adikrao., Veeresh B. Combination of lauric acid and myristic acid prevents benign prostatic hyperplasia ( $\mathrm{BPH}$

and Growth of Prostatic Carcinoma Cell Line LNCap-FGC by Natural Astaxanthin and Saw Palmetto Lipid Extract In Vitro. J Herb Pharmacother. 2005;5(1):17-26. doi:DOI: 10.1080/J157v05n01_03

66. Bombardelli E GC. Combinations of extracts of Serenoa repens and lipophilic extracts of Zingiber officinalis and Echinacea angustifolia, the use thereof, and formulations containing them. 2017. United State Patent, US6261607B 1/en. 2017; (Accessed November 2019):6261607.

\section{Peer Reviewed}

Competing Interests: None declared.

\section{Received: 10/21/2020; Accepted: 4/7/2021}

Cite this article as: Aber J, Kaggwa B, Okella H, Ajayi CO, Ogwang PE. A Review on Serenoa Serrulata: Serenoa serrulata antiprostatic medicinal plant. East Afr Science J. 2021: 3(1): 19-33. https://doi.org/10.24248/EASci-D-20-00016

(D) Aber $\mathrm{J}$ et al. This is an open-access article distributed under the terms of the Creative Commons Attribution License, which permits unrestricted use, distribution, and reproduction in any medium, provided the original author and source are properly cited. To view a copy of the license, visit http://creativecommons.org/licenses/by/4.0/. When linking to this article, please use the following permanent link: https://doi.org/10.24248/EASci-D-20-00016 